\title{
Proximate, Antinutrient and Mineral Composition of Commonly Consumed Food from Lima Beans (Phaseolus Lunatus) in Kaduna State, North Western Nigeria
}

\author{
Olumuyiwa Adeyemi Owolabi ${ }^{1 *}$, Charity Baliyat Dankat ${ }^{2}$, Ijeoma Okolo ${ }^{3}$, and Kola Matthew Anigo ${ }^{4}$ \\ ${ }^{1-4}$ Department of Biochemistry, Ahmadu Bello University
}

Zaria, Kaduna State

Nigeria.

\begin{abstract}
This study was conducted to determine some of the nutrient and anti-nutritional factors in commonly consumed Lima beans (Phaseolus lunatus) foods in Kaduna State, Nigeria. The foods include lima bean porridge, lima bean-benniseed and lima beanhungry rice. The foods were subjected to proximate, minerals and antinutrients analysis using standard procedures and analytical methods. Proximate composition shows that lima bean-benniseed food had higher content of crude protein (8.33\%), crude fat $(13.46 \%)$, crude fibre $(4.09 \%)$ and ash $(2.28 \%)$ compared to other foods while lima bean porridge had significantly $(P<0.05)$ higher carbohydrate (24.58\%) content than other foods. The protein content of lima bean porridge and lima bean-benniseed foods were significantly $(P<0.05)$ higher than lima bean-hungry rice food. The mineral content $\mathrm{Zn}, \mathrm{K}, \mathrm{Mg}$, and Ca of lima beanbenniseed food were significantly $(P<0.05)$ higher than other foods. Zn content was very low and ranged from $0.40 \pm 0.01$ to $0.66 \pm 0.01$ for lima bean-hungry rice and lima bean-benniseed respectively. Lima bean porridge had higher content of iron and sodium. The iron content range was from $4.31 \pm 0.02$ to $5.83 \pm 0.03$ while sodium content range was from $17.45 \pm 0.02$ to $23.88 \pm 0.01$. Antinutrients cyanide, tannin and phytate content in all the foods decreased significantly $(P<0.05)$ when compared with raw lima beans; lima bean-hungry rice food had significantly $(P<0.05)$ lower content of tannin than other foods. This study shows that foods prepared with lima beans possess good nutritional profile and an increase in consumption of these foods has potential to improve dietary diversity, decrease malnutrition and its debilitating effects, especially for the vulnerable group which includes children, women and the elderly.
\end{abstract}

Keywords: Lima bean food, Mineral composition, Antinutrient, Proximate.

\subsection{INTRODUCTION}

Diets usually consist of complex food aggregates and an inadequate diet results to malnutrition [1]. According to the World Health Organization [2], malnutrition is one of the leading causes of death globally. In Nigeria more than half of children under five years of age are either stunted or wasted [3]. Food-based approaches such as; dietary diversification, fortification and biofortification are necessary strategies to prevent the debilitating effects of malnutrition by promoting the consumption of foods that are naturally rich in micronutrients. Dietary diversification reflects household access to varieties of foods and can also act as a proxy for individuals' nutrient adequacy. Brian and Leslie [4], suggested some dietary strategies that could be implemented at the household level to prevent malnutrition, these include; increasing energy and nutrient density of food; increasing the production and consumption of micronutrient dense foods; incorporating enhancers of micronutrient absorption in household diets and employing germination, fermentation, and soaking to reduce anti-nutrient content of cereals and legumes.

Lima beans are important source of protein and dietary fiber. It can be substituted for animal protein especially for people who cannot afford to obtain protein from animal sources [5]. This can help in combating protein malnutrition especially in developing countries and among vulnerable groups. In developing countries, research attention is being paid to better utilization of legumes in addressing protein malnutrition and problems of food security, hence the need for this research. 
International Journal of Advances in Scientific Research and Engineering (ijasre), Vol 6 (6), June -2020

\subsection{MATERIALS AND METHODS}

\subsection{Materials}

Dry Lima beans (Phaseolus lunatus) and all ingredients were purchased from Sabo market in Kaduna South Local Government Area of Kaduna State, Nigeria. The seeds were identified at the herbarium of Department of Botany, Ahmadu Bello University, Zaria, Kaduna state, Nigeria, and voucher number (2403) was deposited. The seeds were kept at room temperature. All chemicals and reagents used were of analytical grade.

\subsection{Lima Bean Foods Recipe}

\begin{tabular}{|c|c|c|}
\hline Lima bean Porridge & Lima bean-Hungry rice & Lima bean-Benniseed \\
\hline Ingredients & Ingredients & Ingredients \\
\hline Lima beans $(g)$ & Lima beans $(g)$ & Lima beans $(g)$ \\
\hline $\operatorname{Beef}(g)$ & Hungry rice $(g)$ & Benniseed $(g)$ \\
\hline Curry $(g)$ & $\operatorname{Beef}(g)$ & Beef $(g)$ \\
\hline Thyme (g) & Curry $(g)$ & Curry $(g)$ \\
\hline Salt $(g)$ & Thyme $(g)$ & Thyme $(g)$ \\
\hline Water $(m l)$ & Salt $(g)$ & Salt $(g)$ \\
\hline Tomatoes $(g)$ & Bouillon cubes & Water $(m l)$ \\
\hline Onions $(g)$ & Water $(\mathrm{ml})$ & Tomatoes $(g)$ \\
\hline Palm oil $(\mathrm{ml})$ & Palm oil $(\mathrm{ml})$ & Onions $(g)$ \\
\hline Red Pepper (g) & Tomatoes $(g)$ & Palm oil $(\mathrm{ml})$ \\
\hline Bouillon cubes & Onions $(g)$ & Pepper $(g)$ \\
\hline Groundnut oil $(\mathrm{ml})$ & $\begin{array}{l}\text { Pepper }(\mathrm{g}) \\
\text { Groundnut oil }(\mathrm{ml})\end{array}$ & $\begin{array}{l}\text { Bouillon cubes } \\
\text { Groundnut oil }(\mathrm{ml})\end{array}$ \\
\hline $\begin{array}{l}\text { Preparation } \\
\text { Step } 1 \text { Rinsed beans } \\
\text { Step } 2 \text { Par-boiled beans for } 1 \text { hour } \\
\text { Step } 3 \text { Seasoned beef with bouillon } \\
\text { cubes, thyme, curry, onions, salt and } \\
\text { cooked for } 40 \text { minutes } \\
\text { Step } 4 \text { Drained beans and par-boiled a } \\
\text { second time for } 20 \text { minutes after which } \\
\text { the beans were drained } \\
\text { Step } 5 \text { Poured groundnut oil into frying } \\
\text { pan and heated for } 2 \text { minutes then fried } \\
\text { beeffor } 15 \text { minutes } \\
\text { Step } 6 \text { Sliced tomatoes, pepper and } \\
\text { onions } \\
\text { Step } 7 \text { Poured palm oil into the pot and } \\
\text { heated for } 2 \text { minutes then added the } \\
\text { sliced ingredients and fried for } 10 \\
\text { minutes } \\
\text { Step } 8 \text { Added } 340 m l s \text { of broth from } \\
\text { cooked beef and brought to a boil } \\
\text { Step } 9 \text { Added beans and allowed to cook } \\
\text { for } 20 \text { minutes }\end{array}$ & $\begin{array}{l}\text { Preparation } \\
\text { Step } 1 \text { Cleaned and rinsed hungry rice } \\
\text { Step } 2 \text { Par-boiled beans for } 1 \text { hour } \\
\text { Step } 3 \text { Seasoned beef with curry, thyme, } \\
\text { bouillon cubes, onions, salt and cooked } \\
\text { for } 40 \text { minutes } \\
\text { Step } 4 \text { Drained beans and parboiled a } \\
\text { second time for } 20 \text { minutes after which } \\
\text { the beans were drained } \\
\text { Step } 5 \text { Poured groundnut oil into frying } \\
\text { pan and heated for } 3 \text { minutes then fried } \\
\text { beeffor } 15 \text { minutes } \\
\text { Step } 6 \text { Sliced tomatoes, pepper and } \\
\text { onions } \\
\text { Step } 7 \text { Poured palm oil into the pot and } \\
\text { heated for } 2 \text { minutes then added the } \\
\text { sliced ingredients and fried for } 10 \\
\text { minutes } \\
\text { Step } 8 \text { Added } 900 \text { ml of water (beef stock } \\
\text { inclusive) and brought to boil } \\
\text { Step } 9 \text { Added beans and hungry rice and } \\
\text { cooked for } 10 \text { minutes }\end{array}$ & $\begin{array}{l}\text { Preparation } \\
\text { Step } 1 \text { Rinsed beans and Par-boiled } \\
\text { beans for } 1 \text { hour } \\
\text { Step } 2 \text { Seasoned beef with bouillon } \\
\text { cubes, thyme, curry, onions, salt and } \\
\text { cooked for } 40 \text { minutes } \\
\text { Step } 3 \text { Drained beans and par-boiled a } \\
\text { second time for } 20 \text { minutes after which } \\
\text { the beans were drained } \\
\text { Step } 4 \text { Roasted benniseed for } 3 \text { minutes } \\
\text { Step } 5 \text { Grinded benniseed } \\
\text { Step } 6 \text { Poured groundnut oil into frying } \\
\text { pan and heat for } 2 \text { minutes then put beef } \\
\text { into oil and fried for } 15 \text { minutes } \\
\text { Step } 7 \text { Sliced tomatoes, pepper and } \\
\text { onions } \\
\text { Step } 8 \text { Poured palm oil into the pot and } \\
\text { heat for } 2 \text { minutes then added the sliced } \\
\text { ingredients and fried for } 10 \text { minutes } \\
\text { Step } 9 \text { Added } 340 m \text { of of broth from } \\
\text { cooked beef and brought to a boil } \\
\text { Step } 10 \text { Added beans and allowed to cook } \\
\text { for } 20 \text { minutes } \\
\text { Step } 11 \text { Stirred in benniseed to cooked } \\
\text { beans }\end{array}$ \\
\hline
\end{tabular}

\subsection{Proximate Analysis}

Proximate analysis was done using the methods as described by the AOAC [6]. The moisture content of the food recipes was determined after drying at $105^{\circ} \mathrm{c}$ until a constant weight was obtained. The ash content was estimated after heating in an ashing muffle furnace for $12 \mathrm{~h}$ at $550^{\circ} \mathrm{c}$. The micro-kjeldahl method was employed to determine the total nitrogen and the crude protein estimated by multiplying the total nitrogen $(\mathrm{N})$ by 6.25 . Crude lipid was extracted with petroleum ether using the soxhlet apparatus. Total carbohydrate was calculated by difference. 


\subsection{Mineral Analysis}

Calcium, iron, potassium, zinc, sodium and magnesium were determined by atomic absorption spectrophotometry (FAAS, AA 500 model) after digestion with concentrated nitric acid [6]

\subsection{Antinutrient Analysis}

Phytate content was determined using the procedure described by Lucas and Markakas [7]. Tannin was estimated according to the method described by Makkar et al. [8], while cyanide content was determined according to the alkaline titration method as described by AOAC [6]

\subsection{Statistical Analysis}

The results are expressed as mean \pm standard deviation except where otherwise stated. The Data were analyzed by descriptive statistics and Analysis of variance (ANOVA) using Statistical Package for the Social Sciences (SPSS), version 20. Duncan multiple range test was used for multiple mean comparison tests and $\mathrm{P}$ values less than $0.05(\mathrm{P}<0.05)$ was taken as significant.

\subsection{RESULTS}

\subsection{Proximate Composition of Commonly Consumed Lima Bean (Phaseolus lunatus) Foods in Kaduna State}

Proximate compositions of the foods are presented in Table 1. The result shows that the foods had significantly $(\mathrm{P}<0.05)$ higher moisture and crude fat content than raw lima bean. Lima bean-benniseed food had significantly $(\mathrm{P}<0.05)$ higher crude fat, crude fibre and ash contents than other foods while lima bean porridge had significantly $(\mathrm{P}<0.05)$ higher carbohydrate content than lima bean-hungry rice and lima bean-benniseed foods. The protein content of lima bean porridge and lima bean-benniseed foods were significantly $(\mathrm{P}<0.05)$ higher than lima bean-hungry rice food.

Table 1. Proximate Composition of Commonly Consumed Lima Bean (Phaseolus lunatus) Foods in Kaduna State.

\begin{tabular}{|c|c|c|c|c|}
\hline \multirow{2}{*}{$\begin{array}{l}\text { Proximate } \\
\text { content }(\%)\end{array}$} & \multirow[t]{2}{*}{ Raw Lima bean } & \multicolumn{2}{|c|}{ Lima bean foods } & \multirow[b]{2}{*}{ Bean-benniseed } \\
\hline & & Bean porridge & Bean-hungry rice & \\
\hline Moisture & $10.80 \pm 0.06^{\mathrm{a}}$ & $54.28 \pm 0.02^{\mathrm{b}}$ & $67.22 \pm 0.02^{\mathrm{d}}$ & $55.26 \pm 0.05^{\mathrm{c}}$ \\
\hline Crude Protein & $19.45 \pm 0.05^{\mathrm{c}}$ & $8.30 \pm 0.06^{\mathrm{b}}$ & $4.66 \pm 0.04^{\mathrm{a}}$ & $8.33 \pm 0.05^{\mathrm{b}}$ \\
\hline Crude Fat & $1.60 \pm 0.02^{\mathrm{a}}$ & $10.61 \pm 0.02^{c}$ & $8.29 \pm 0.01^{b}$ & $13.46 \pm 0.02^{\mathrm{d}}$ \\
\hline Crude Fibre & $6.01 \pm 0.01^{\mathrm{d}}$ & $3.05 \pm 0.01^{\mathrm{b}}$ & $2.25 \pm 0.01^{\mathrm{a}}$ & $4.09 \pm 0.02^{\mathrm{c}}$ \\
\hline Ash & $4.86 \pm 0.05^{\mathrm{d}}$ & $2.20 \pm 0.02^{b}$ & $1.58 \pm 0.01^{\mathrm{a}}$ & $2.28 \pm 0.02^{\mathrm{c}}$ \\
\hline Carbohydrate & $63.29 \pm 0.03^{\mathrm{d}}$ & $24.58 \pm 0.05^{\mathrm{c}}$ & $18.25 \pm 0.03^{\mathrm{a}}$ & $20.70 \pm 0.03^{b}$ \\
\hline
\end{tabular}

Values are mean \pm S.D of three determinations (based on wet weight for lima bean foods); abcd= mean values with different superscript across the rows are significantly $(\mathrm{P}<0.05)$ different.

\subsection{Mineral composition of Commonly Consumed Lima Bean (Phaseolus lunatus) Foods in Kaduna State}

The mineral composition of commonly consumed lima beans foods is shown in Table 2. The result shows that Ca, Mg, K, Fe and $\mathrm{Zn}$ content of raw beans was significantly $(\mathrm{P}<0.05)$ higher than the food recipes. Lima bean-benniseed food had significantly $(\mathrm{P}<0.05)$ higher content of $\mathrm{Ca}, \mathrm{Mg}, \mathrm{K}$ and $\mathrm{Zn}$ than other foods while lima bean porridge food had significantly $(\mathrm{P}<0.05)$ higher Fe and $\mathrm{Na}$ content than other food recipes. 
International Journal of Advances in Scientific Research and Engineering (ijasre), Vol 6 (6), June -2020

Table 2. Mineral Composition of Commonly Consumed Lima Bean (Phaseolus lunatus) Foods in Kaduna state.

\begin{tabular}{|c|c|c|c|c|}
\hline \multirow{2}{*}{$\begin{array}{l}\text { Mineral } \\
\text { Content } \\
(\mathrm{mg} / \mathbf{1 0 0 g})\end{array}$} & \multirow[t]{2}{*}{ Raw Lima bean } & \multicolumn{2}{|c|}{ Lima bean foods } & \multirow[b]{2}{*}{ Bean-benniseed } \\
\hline & & Bean porridge & Bean-hungry rice & \\
\hline $\mathrm{Ca}$ & $89.00 \pm 1.00^{\mathrm{d}}$ & $44.58 \pm 0.02^{\mathrm{b}}$ & $35.26 \pm 0.04^{\mathrm{a}}$ & $61.40 \pm 0.04^{c}$ \\
\hline $\mathrm{Mg}$ & $309.33 \pm 0.76^{\mathrm{d}}$ & $62.44 \pm 0.02^{\mathrm{b}}$ & $40.54 \pm 0.03^{\mathrm{a}}$ & $91.62 \pm 0.06^{c}$ \\
\hline K & $3945.00 \pm 5.00^{\mathrm{d}}$ & $1016.53 \pm 0.50^{\mathrm{b}}$ & $544.95 \pm 0.42^{\mathrm{a}}$ & $1068.52 \pm 0.66^{\mathrm{c}}$ \\
\hline $\mathrm{Na}$ & $7.25 \pm 0.25^{\mathrm{a}}$ & $23.88 \pm 0.01^{\mathrm{d}}$ & $17.45 \pm 0.02^{\mathrm{b}}$ & $23.25 \pm 0.01^{c}$ \\
\hline $\mathrm{Fe}$ & $7.93 \pm 0.08^{\mathrm{d}}$ & $5.83 \pm 0.03^{\mathrm{c}}$ & $4.88 \pm 0.01^{\mathrm{b}}$ & $4.31 \pm 0.02^{\mathrm{a}}$ \\
\hline $\mathrm{Zn}$ & $1.74 \pm 0.01^{\mathrm{d}}$ & $0.54 \pm 0.02^{b}$ & $0.40 \pm 0.01^{\mathrm{a}}$ & $0.66 \pm 0.01^{\mathrm{c}}$ \\
\hline
\end{tabular}

Values are mean \pm S.D of three determinations (based on wet weight for lima bean foods); abcd= mean values with different superscript across the rows are significantly $(\mathrm{P}<0.05)$ different.

\subsection{Antinutritional composition of Commonly Consumed Lima Bean (Phaseolus lunatus) Foods in Kaduna State \\ Antinutrient content of commonly consumed lima bean foods is shown in Table 3. The result shows that the three food recipes had significantly $(\mathrm{P}<0.05)$ lower levels of cyanide, tannin and phytate than raw lima bean; Lima bean-hungry rice food had significantly $(\mathrm{P}<0.05)$ lower content of tannin than other foods.}

Table 3. Antinutrient Composition of Commonly Consumed Lima Bean (Phaseolus lunatus) Foods in Kaduna State.

\begin{tabular}{|c|c|c|c|c|}
\hline \multirow{2}{*}{$\begin{array}{l}\text { Antinutrient content } \\
(\mathrm{mg} / \mathbf{1 0 0 g})\end{array}$} & \multicolumn{2}{|c|}{ Raw Lima bean } & \multicolumn{2}{|c|}{ Lima Beans Foods } \\
\hline & & Bean porridge & Bean-hungry rice & Bean-benniseed \\
\hline Tannin & $12.75 \pm 0.01^{\mathrm{c}}$ & $4.15 \pm 0.21^{\mathrm{a}}$ & $3.83 \pm 0.35^{\mathrm{d}}$ & $6.00 \pm 0.28^{b}$ \\
\hline Phytate & $4.88 \pm 0.00^{\mathrm{d}}$ & $2.93 \pm 0.04^{\mathrm{c}}$ & $2.20 \pm 0.04^{\mathrm{a}}$ & $2.59 \pm 0.04^{\mathrm{b}}$ \\
\hline Cyanide & $1.15 \pm 0.08^{\mathrm{d}}$ & $0.29 \pm 0.02^{\mathrm{b}}$ & $0.43 \pm 0.04^{\mathrm{c}}$ & $0.14 \pm 0.01^{\mathrm{a}}$ \\
\hline
\end{tabular}

Values are mean \pm S.D of three determinations (based on wet weight for lima bean foods); abcd= mean values with different superscript across the rows are significantly $(\mathrm{P}<0.05)$ different. 


\subsection{DISCUSSION}

The moisture content of the raw beans is lower than that of the prepared foods; this may be the basis for its long shelf life and less susceptibility to microbial attack during storage. The increased moisture content $(67 \%)$ in lima bean-hungry rice suggests that it would not have longer shelf-life compared to the other lima beans foods since the higher the moisture content of a food, the lower its shelf-life as commonly observed with processed foods. Processing of raw lima beans into lima bean foods resulted in significant reduction of nutrient values except for crude fat. The observed reduction in nutrient value is believed to be due to increase in moisture content of the prepared foods because some nutrients leach out into the cooking water. This makes it important for cooking liquid to be consumed whenever possible. Percentage loss of nutrients may also depend partly on destruction of the nutrients by heat and chemical changes such as oxidation [9]. The increase in crude fat is due to addition of palm oil during recipe preparation which has a total fat value of $153 \%$ and about $50 \%$ saturated fatty acids [10]. Lima beanbenniseed and lima bean porridge foods can serve as good sources of plant protein since they recorded higher protein content. This justifies their use as a source of cheap protein especially amongst poor populace in Nigeria who consume less of animal protein [11].

Crude fat content is higher in lima bean-benniseed food at $13.46 \%$; this is due to the high fat content (49.51\%) of raw benniseed as reported by Adegunwa et al.[12], compared with raw hungry rice and lima beans. Crude fibre content (4.09\%) and ash content (2.28\%) of lima bean-benniseed food were also higher than other foods which could be an added advantage to the functioning of the digestive system and help in decreasing the risk for developing coronary heart disease and hypertension [13]. The carbohydrate content of all the foods can serve as a major source of energy for the body since carbohydrates are the body's preferred fuel source. The high ash content for bean-benniseed food provides a measure of the mineral content of these foods [14]. Minerals are inorganic nutrients that are required by the body in small amount and are necessary for the maintenance of certain chemical processes which are essential to life. The values of minerals obtained were in line with results obtained for two cultivars of beans as reported by Bamigboye and Adepoju [11]. Lima bean-benniseed food had higher content of potassium (K) $(1068.52 \mathrm{mg} / 100 \mathrm{~g})$. Potassium $(\mathrm{K})$ was the most predominant mineral observed which is in agreement with several reports according to Seidu et al. [5], that potassium is the most predominant mineral element in Nigerian agricultural products. The high potassium content $(1068.52 \mathrm{mg} / 100 \mathrm{~g})$ and low sodium $(\mathrm{Na})$ content $(23.25 \mathrm{mg} / 100 \mathrm{~g})$ of lima bean-benniseed food could be advantageous in reducing high blood pressure since the $\mathrm{Na} / \mathrm{K}$ ratio in the body is important in the prevention and management of high blood pressure. Calcium $(\mathrm{Ca})$ is essential in bone formation; the high calcium content of this food could serve as a good complementary food for infants. Lima bean porridge food recorded higher iron $(\mathrm{Fe})$ content $(5.83 \mathrm{mg} / 100)$. Iron requirement in the body vary with age and gender, more iron is required during pregnancy, menstruation and growth. These foods could serve as an additional source of dietary iron.

Phytic acids are known to interfere with calcium, zinc, magnesium and iron utilization by forming insoluble complexes with these mineral elements [12]. The amount of cyanide ranged from $0.14 \mathrm{mg} / 100 \mathrm{~g}$ in bean-benniseed recipe to $1.15 \mathrm{mg} / 100 \mathrm{~g}$ in the raw sample. The observed result shows that there was a reduction in cyanide content in the prepared foods when compared to raw lima beans. Reduction of cyanide especially in lima bean-benniseed could be as a result of roasting of the benniseed during food preparation which is in accordance with Adegunwa et al.[12], report which elucidated that roasting leads to more reduction in cyanide content of benniseed compared to other thermal treatments. Low levels of phytate and tannins were reported to lower serum cholesterol [15]. Lima bean-hungry rice with the least phytate content $(2.20 \mathrm{mg} / 100 \mathrm{~g})$ and lima bean porridge with the least tannin $(4.15 \mathrm{mg} / 100 \mathrm{~g})$ content could contribute to lowering of cholesterol level in the body.

\section{CONCLUSION}

Nutrient profiles of these foods are established and it is concluded that the food products from lima beans possess good nutritional profile, however, lima bean-benniseed food has the best nutrient profile.

\section{CONFLICT OF INTEREST STATEMENT}

None

\section{ACKNOWLEDGEMENT}

We thank Mr. Adeshina Adeleke for his technical support. 


\section{REFERENCES}

1. R. David and Jr. Jacobs, “ Nutritional Health: Strategies for Disease Prevention”, Temple, N. J. and T. Wilson, Eds. pp. 25-29.

2. World Health Organization. 2013. Global Nutrition policy review. What does it take to scale up nutrition action? Available from http://apps.who.int/iris/bitstream/10665/84408/1/9789241505529 [Accessed 11 November 2016].

3. National Nutrition and Health Survey. 2015. 2015 Report on the Nutrition and Health situation of Nigeria. Available from https://www.unicef.org/nigeria/NNHS2015_Final.pdf [Accessed 20 November 2016].

4. T. Brain and A. Leslie, "Combating Micronutrient Deficiencies" Food-based Approaches Edn., Food Agriculture Organization of the United Nations, pp.20-30, 2011.

5. K. T. Seidu, O.F. Osundahunsi, M. T. Olaleye and I. B. Oluwalana, "Chemical Composition, Phytochemical Constituents and Antioxidant Potentials of Lima Bean seeds coat" Annals of Food science and Technology, 15(2), pp. 288 - 298, 2014.

6. Association of Organic and Analytical Chemistry, Official Methods of Analysis of AOAC International, $17^{\text {th }}$ ed., Gaithersburg, MD, USA: AOAC. 2000.

7. G.M. Lucas and P. Markakas, "Phytic acid and other Phosphorus Compounds of Bean (Phaseolus vulgaris)" Journal of Agriculture Education and Chemistry, vol. 23, pp.13- 15, 1975.

8. H.P.S. Makkar M. Blumel, N.K. Borowy and K. Becker, "Gravimetric Determination of Tannins and their Correlations with Chemical and Protein Precipitation Methods” Journal of Science and food Agriculture, 61, pp.161- 165, 1993.

9. Food and Agriculture Organization of the United Nations, "Roots, Tubers, Plantains and Bananas in Human Nutrition". Effects of Processing on Nutrition Value, 1990, pp 2-3.

10. O. B. Imoisi, G. E. Ilori, I. Agho, and J. O. Ekhator, "Palm oil, its nutritional and Health implications" Journal of Applied Science and Environment, 19(1), pp.127-133, 2015.

11. A.Y. Bamigboye and O. T. Adepoju, "Effects of Processing Methods on Nutritive Values of Ekuru from Two Cultivars of Beans (Vigna unguiculata and Vigna angustifoliata)," African Journal of Biotechnology, 14(21), pp.1790-1795, 2015.

12. M.O. Adegunwa, A.A. Adebowale, and E.O. Salaro, "Effect of Thermal Processing on the Biochemical Composition, Antinutritional factors and Functional properties of Beniseed (Sesamum indicum) flour," American Journal of Biochemistry and molecular Biology, 2(3), pp.175-182, 2012.

13. H.A. Oboh and C.O. Omofoma, "The Effects of Heat Treated Lima Beans (Phaseolus lunatus) on Plasma lipids in Hypercholesterolemic rats" Pakistan Journal of Nutrition, 7(5), pp. 636-639, 2008.

14. M.D. Awogbenja and F.U. Ugwuona, "Nutrient and Phytochemical Composition of some Commonly Consumed Traditional Dishes of Nasarawa State, Nigeria," Journal of Production Agriculture and Technology, 8(1), pp.30-39, 2012.

15. E. U. Madukwe, R. I. Edeh and I. O. Obizoba, "Nutrient and Organoleptic Evaluation of Cereal and Legume based Cookies" Pakistan Journal of Nutrition, 12(2), pp. 154-157, 2013. 